\title{
Climate Governance Initiatives: Snapshots from Bangladesh
}

\author{
Md. Mafizur Rahman, Dong Huang \\ College of Public Administration, Huazhong University of Science and Technology, Wuhan, China \\ Email: rahmanmm_jnu@yahoo.com,hd7269@126.com
}

How to cite this paper: Rahman, M. M., \& Huang, D. (2019). Climate Governance Initiatives: Snapshots from Bangladesh. Journal of Geoscience and Environment Protection, 7, 131-147.

https://doi.org/10.4236/gep.2019.79010

Received: May 27, 2019

Accepted: September 23, 2019

Published: September 26, 2019

Copyright $\odot 2019$ by author(s) and Scientific Research Publishing Inc. This work is licensed under the Creative Commons Attribution International License (CC BY 4.0).

http://creativecommons.org/licenses/by/4.0/

\section{cc) (i) Open Access}

\begin{abstract}
Bangladesh is often cited as one of the most vulnerable countries to the effects of climate change. The impacts of climate change are exacerbating the existing poverty and inequality challenges in Bangladesh. Adaption and mitigation to climate change are now unavoidable demands and considered as realistic actions to help the survival of humans. The objective of this paper is to explore the role of "governance" to promote mitigation of, and adaptation to human induced climate change. The study considers "governance" as a mechanism of the effective policy measures and implementation, responsible state and non-state institutions and the active civic participation in this process.
\end{abstract}

\section{Keywords}

Climate Change, Governance, Climate Governance

\section{Introduction}

The earth is getting warmer. As a result, climate change is happening here and now. In the contemporary era, climate change is arguably the most important challenge facing the world community. The effects of climate change can cause social problems, especially where the houses, industries, ports or other advanced areas are located. Potential possible impacts and their effects reveal the number of stakeholders, activity fields, and interests affected by climate change (Fröhlich \& Knieling, 2013). Bangladesh is considered as one of the most vulnerable countries of the world to extreme effects of climate change. Nowadays, climate change related risks and vulnerabilities are also critical for development issues for Bangladesh. The country is already experiencing stepped-up climate change impacts like floods, droughts, storm surges, rise in sea level, tropical cyclones 
combined with a high population and growth, and low climate resilience. Over the last decade, Bangladesh has adopted and implemented various plans and policies and is heavily investing in adaption measures to systematically reduce climate-change impacts. However, institutional arrangements and an integrated strategy for adaptation of climate change have not been implemented yet.

\section{Impact of Climate Change in Bangladesh}

Impacts of climate change have been witnessed in Bangladesh: summers are becoming hotter, monsoons have been irregular, rainfall is untimely, heavy rainfall over a short period causing waterlogging and landslides have been observed, the occurrence of very little rainfall in dry periods, increased river flow and inundation during monsoon, increased frequency, intensity and recurrence of floods, crop damage due to flash floods and monsoon floods, crop failure due to drought, prolonged cold spells, salinity intrusion along the coast leading to scarcity of potable water and redundancy of prevailing crop practices, coastal erosion, river bank erosion, deaths due to extreme heat and extreme cold, increasing mortality, morbidity, prevalence and outbreak of cholera, and diarrhea, etc. (Kabir et al., 2016) (Figure 1).

Changing climates will mean more extreme weather that would bring about disasters from heatwaves to hurricanes, and from floods to famines (Vidal, 2017). Bangladesh has been featured on the Guardian's list of seven climate change hotspots. Bangladesh's vulnerability to climate change is now universally acknowledged. The country has also been ranked seventh among the countries most affected by extreme weather events in 20 years since 1998 in Global Climate Risk Index 2019. The report was prepared analysing damages caused by the extreme weather events that took place from 1998 to 2017 (Eckstein, Künzel, \& Schäfer, 2017).

In the last 30 years, the country has experienced nearly 200 climate-related disasters including drought, extreme temperatures, floods, and storms. These events have killed thousands of people, destroyed homes and livelihoods, and cost approximately $\$ 16$ billion in damages (Oxfam International, 2011).

Climate change creates insecurities for food, water, life, property, settlement, livelihoods, and so on in Bangladesh. Environmental degradation, and degradation of land resources ultimately reduce food and health securities, and other issues. Increased cyclones, storm surges, floods, and river-bank erosion destroy and damage people's properties, which include land, house, cattle, and other livelihood assets and living essentials. Frequent disasters increase damage and losses by many folds. Due to climate change, river-bank, and coastal erosion are increasing at an alarming rate. Climate risks for Bangladesh are as follows (Table 1).

Bangladesh is considered as one of the countries that are most vulnerable to the effects of climate change and the country's coastal areas are facing the biggest risks. In recent years, Bangladesh was hit by two consecutive cyclones-Sidr in 


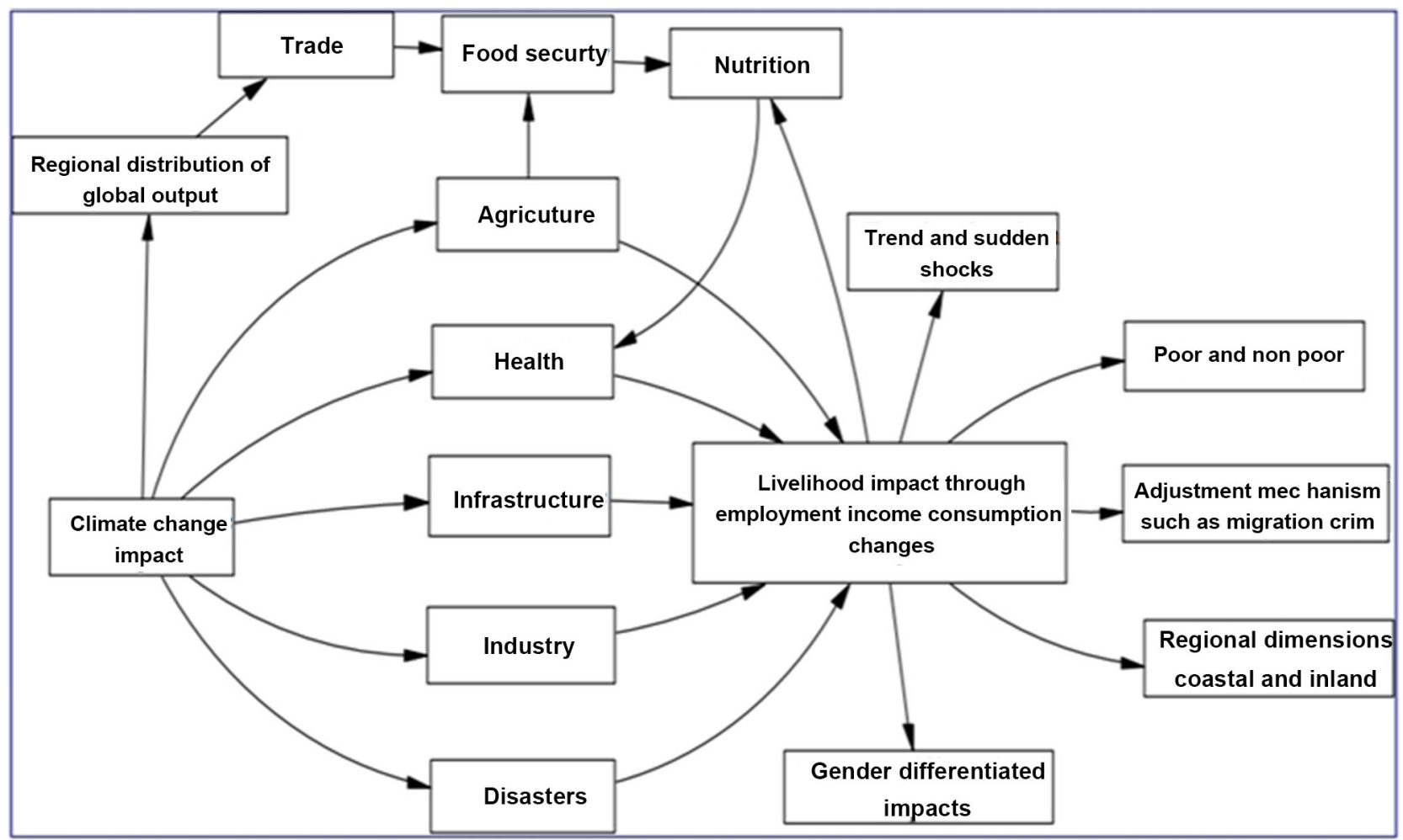

Figure 1. Intensity of impacts on different sectors due to climate change (adopted from Ministry of Environment and Forests (MoEF), 2005).

Table 1. Climate change impacts in Bangladesh.

\begin{tabular}{ll}
\hline \multicolumn{1}{c}{ Environmental Impact } & Socio-Economic Resources \& Sectors Affected \\
\hline - Changes in rainfall patterns & - Water resources \\
- Increased frequency and severity of: & - Agriculture and forestry \\
- Floods & - Food security \\
- Droughts & - Human health \\
- Storms & - Infrastructure (e.g. transport) \\
- Heat waves & - Settlements: displacement of inhabitants and \\
- Changes in growing seasons and regions & loss of livelihood \\
- Changes in water quality and quantity & - Coastal management \\
- Sea level rise & - Industry and energy \\
- Glacial melt & - Disaster response \& recovery plans \\
\hline
\end{tabular}

2007, and Aila in 2009. According to Paul (2009), cyclone Sidr, which hit Bangladesh on the 15th of November, 2007, caused about 3406 deaths and over 55,000 physical injuries. Cyclone Sidr affected nine districts of Bangladesh. The most devastated districts were Bagerhat, Barguna, Patuakhali, and Pirojpur (Davidson, 2008). Heavy rain accompanying cyclones and tidal waves due to wind effects caused extensive physical destruction, casualties, damage of crops and livestock, and flooding across the South Western coastal districts of Bangladesh (Kabir et al., 2016). Cyclone Aila hit the southern coastline of Bangladesh devastatingly on the 25th of May, 2009. It was an extraordinary event since a storm of this nature had not hit the Sundarbans in the last three decades before cyclone 
Aila (Das, 2009). The Bangladeshi districts of Satkhira and Khulna suffered the heaviest damage along with Bagerhat, Pirojpur, Barishal, Patuakhali, Bhola, Lakshmipur, Noakhali, Feni, Chittagong, and Cox’s Bazar (Roy et al., 2009).

\section{Climate Governance: A Conceptual Schema}

Climate governance is in a state of enormous flux (Jordan et al., 2018). A clear and precise definition of "climate governance" is crucial for studying governance structure. In fact, there is still considerable debate over the term "governance" itself. Although there is no agreed definition of governance, it can be seen in narrow and boarder terms as to it has to do with. The narrow view considers "governance" as to governments and the process of regulating the private, and public sectors (Pierre, 2002). In the same tune, Rosenau (1992) sees "governance" as a more encompassing phenomenon than "government". It embraces governmental institutions, but it also subsumes informal, non-governmental mechanisms whereby those persons and organizations within its purview move ahead, satisfy their needs, and fulfill their wants.

A broader view on the other hand, sees governance as the governing mechanisms that do not rest on recourse to the authority and sanctions of government (Stoker, 1998). Stoker (1998) also suggested that governance is about a framework for "understanding changing processes of governing", provided what he termed as the five "propositions" that define governance. These are:

- Governance refers to a set of institutions and actors that are drawn from but also beyond government.

- Governance identifies the blurring of boundaries and responsibilities for tackling social and economic issues.

- Governance identifies the power dependence involved in the relationships between institutions involved in collective action.

- Governance is about autonomous self-governing networks of actors.

- Governance recognizes the capacity to get things done which does not rest on the power of government to command or use its authority. It sees government as able to use new tools and techniques to steer and guide.

However, in many other cases, "governance" represents "all co-existing forms of collective regulation of societal circumstances: from institutionalized civil society self-regulation through various forms of cooperation between public and private stakeholders to sovereign action by governmental stakeholders" (Fröhlich \& Knieling, 2013; Mayntz, 2006). In this paper, governance refers to "a range of initiatives, regulations, and government decisions aiming to establish cooperation between governmental and non-government sector stakeholders in dealing with a particular issue: climate change" (Doolin et al., 2015). According to some previous studies, the range of initiative and instruments can be classified into three main categories: 1) formal "sovereign/legal instruments" such as environmental law enforcement, 2) "economic measures" such as carbon taxes, and 3) "information sharing" measures to promote policy learning and experience diffusion (Fröhlich \& Knieling; Soltwedel, 2005; Braun \& Giraud, 2009). The key to go- 
vernance is thus coordinating these instruments among different state, non-state, private, and general public stakeholders.

Climate governance goes beyond the science of climate change to look at the social, economic and political issues related to climate change. It approaches climate change from a rights and sustainable development perspective and interrogates political and financial processes involved with achieving change from the global perspective to those of the national and local (IPS, 2014). At the national level, climate governance frameworks take the form of climate change policies that define how climate change will be addressed at national level and the roles and responsibilities of different stakeholders, including government, private sector, civil society and affected citizens. Climate governance requires governments to take an active role in bringing about shifts in interest perceptions so that stable societal majorities in favor of deploying an active mitigation and adaptation policy regime can be maintained. Measures to help effect such change include: building coalitions for change, buying off opponents, establishing new centers of economic power, creating new institutional actors, adjusting legal rights and responsibilities, and changing ideas and accepted norms and expectations (Meadowcroft, 2009).

The extremely dangerous nature of climate change is characterized by the scope and scale of its potential impacts and the inherent uncertainty it presents. Recognizing that multiple futures are possible underlies the need for robust decision-making frameworks that can respond as issues and information emerge over time. Climate governance is paramount in this regard (Edwards, Burton, \& Baker-Jones, 2017). Appropriate governance tracks climate risk management and adaptive action against a dynamic evidence-based environment. It is interesting to note that government might not be able to rescue everybody from the effects of climate change. From this, a general question remains-what then is the government's role in this respect. Contemporary tendency of government is to position itself less hierarchical within society (Kettl, 2002; Salamon \& Elliott, 2002; Frederickson \& Smith, 2003; Hill \& Lynn, 2005). New Public Management proponents, Osborne \& Gaebler (1992), for instance, have argued that governments should do the steering rather than the rowing. It fits in with the popular narrative of a proclaimed shift from "government" to "governance". During the last decades, it has become common in the scientific field of public management and political science to promote a shift from hierarchical and well-institutionalized forms of government towards less formalized forms of governance (Hanf \& Scharpf, 1978; Ostrom, 1990; Marin \& Mayntz, 1991; Rhodes, 1997; Glasbergen, 1998; Pierre \& Peters, 2000; Blatter, 2003; Arts \& Leroy, 2006).

Basically, governance includes both network and hierarchy; it includes both structure and process and it stresses the multilevel character. Despite its obvious connotation, governance is, therefore, not primarily a matter of government. This approach is very much relevant concerning the role of government in the case of tackling the effects of climate change. In other words, we can, thus, label 
"adaptation" as an issue of governance. Now, it has been established why adaptation can be considered a matter of governance. It is argued that governance implies a certain approach to spatial planning. Spatial planning is regarded as a specification of governance, focusing on the spatial dimension involved. The putting into practice of governance implies that a wide variety of actors become involved in the issue of climate adaptation (Van Nieuwaal et al., 2009).

Gaillard (2010) argues that the three concepts of vulnerability, capacities, and resilience can synthesize the factors considered when adaptation strategies are formed. He argues that these concepts can reflect the status of preparedness for people who face natural hazards. It is the push and pull of these three factors that one can view into the challenges that arises when implementing adaptation strategies. Agarwal et al. (2012) proposed "The Adaptation, Institutions and Livelihoods (AIL)" framework which offers the role of institutions and provides three types of local institutions that are relevant to analyzing adaptation within the context of climate change. These local institutions are characterized as civic, public, and private, and they provide "indispensable functions" to the people and shape the extent of how climate-related impacts are felt (Agarwal et al., 2012).

\section{Climate Governance Practice in Bangladesh}

Based on the theoretical underpinnings above, climate governance framework in Bangladesh is molded to a large extent by specific policies, some key formal and informal institutions and their actions. Though it is realized that climate change is a cross-sectoral issue that cuts across many other institutions, these institutions are created and policies are formulated to build resilience. A policy consists of goals and targets, strategies and instruments, implementation mechanisms and impact evaluation provisions. The term, "state institution" commonly applies to particular formal institutions created by entities such as the government and public services. Non-state institutions are not limited to customary institutions but may include newly emerging institutions, developed from the ground up or introduced by external actors, e.g. development partners.

\subsection{Climate Policies}

Climate change will affect all aspects of Bangladesh's development and will be a major barrier for the government's efforts to become a developed country by 2041. This concern resulted in a significant change in the policy and institutional landscape in Bangladesh. Considering trans-national issues, the country is at the center of global climate change discussions, and plays an important role in international climate change politics and diplomacy. Three major initiatives emerged as a result: 1) National Adaptation Programme of Action (NAPA), 2) Climate Change Strategy and Action Plan (BCCSAP), 3) two financing mechanisms-Bangladesh Climate Change Trust Fund (BCCTF), funded by Government of Bangladesh ( $\mathrm{GoB})$ and backed by an Act passed in Parliament; and a donor funded Bangladesh Climate Change Resilience Fund (BCCRF, formerly Multi Donor Trust Fund). 


\subsubsection{National Adaptation Programme of Action (NAPA)}

The country was one of the first least-developed countries (LDCs) to complete its National Adaptation Program of Action (NAPA), citing "urgent and immediate" adaptation needs in 2005. NAPA was funded by United Nations Framework Convention on Climate Change-UNFCCC's LDC Fund (as were NAPAs conducted by other LDCs), and followed guidelines provided by the international community and UNFCCC's LDC Expert Group. It consisted mainly of a list of standalone adaptation actions. The NAPA was updated in 2009 with support from the United Nations Development Programme (UNDP) using funds from the LDC Fund. The updated version of NAPA has identified 38 adaptation measures of which 16 have been further developed for implementation by different ministries and departments. The Ministry of Environment, Forests and Climate Change will facilitate the implementation of identified adaptation measures. It will further pursue raising funds from international level for the implementation of adaptation measures.

\subsubsection{Bangladesh Climate Change Strategy and Action Plan (BCCSAP)} In 2008, the government of Bangladesh prepared and adopted the Bangladesh Climate Change Strategy and Action Plan (BCCSAP). BCCSAP aimed to reflect the changing development priorities of the government, and was eventually revised in 2009 when more areas of action were added, including 1) the development and harnessing of water resources through better management of river course and training, and 2) mitigating policy directions such as the "low-carbon development path".

BCCSAP is the key operational document on climate change. The BCCSAP is treated as part of the overall development strategy of the country. BCCSAP is built on six pillars: 1) food security, social protection, and health; 2) comprehensive disaster management; 3) infrastructure; 4) research and knowledge management; 5) mitigation and low-carbon development; and 6) capacity building and institutional strengthening. Under these thematic pillars, 44 programmes to address climate change challenges have been planned so far.

It is vital that the threat of adverse climate change impacts be addressed now. But financing the implementation of BCCSAP 2009 in itself presents the GoB with a great challenge. Instead of waiting for the international community to provide finance, Bangladesh decided to initiate action with national funds. This led to the creation of two separate funds: The Bangladesh Climate Change Trust Fund (BCCTF), and the Bangladesh Climate Change Resilience Fund (BCCRF). The former is resourced entirely from the government's own budget (USD 100 million annually); and BCCRF comprises of funds pledged and provided by developed countries or groups such as Sweden, the United Kingdom, and the European Union. The two funds have differing governance and management arrangements, but both support BCCSAP (Ministry of Finance, 2014).

\subsubsection{Sixth Five-Year Plan (2011-2015)}

The Sixth Five Year Plan (2011-2015) of Bangladesh provides strategic directions 
and a policy framework, as well as a sectoral development plan. The sixth Five-year Plan recognizes BCCSAP to be the blueprint for the subsequent integration of climate change issues.

\subsubsection{Seventh Five Year Plan (2016-2020)}

The seventh Five Year Plan (2016-2020) proposes several activities for Climate Change Adaptation (CCA). Important among those are promoting a whole-of government approach for climate change, enhancing understanding, knowledge, capacity and coordination, prioritizing programmes and projects, enhancing CCA financing, integrating gender sensitivity in project design, food security, social protection and health, managing hazards and disasters, etc. (Table 2).

\subsubsection{Climate Change Trust Act 2010}

The President officially signed this Act in October, 2011. The main objective is to set up an institutional arrangement to build climate change resilience capacity, as well as to achieve targets which are set under the six pillars of the BCCSAP. All macro and perspective planning, including BCCSAP, are subsequently incorporated into the 7th Five-year Plan (2016-2020).

\subsubsection{Delta Plan 2100}

The government has recently adopted a long-term and holistic plan called "Delta Plan 2100" with the aim of ensuring water and food security, economic progress, and sustainable climate. Adaptation is a critical component of this plan. The short-term measures of the plan will be implemented by 2030, the mid-term ones by 2050, and the long-term ones by 2100 .

Other Sectoral Policies: Some elements of climate change adaptation are addressed through specific sectoral policies (Ahmed, 2004; UO-Oxfam, 2008; Rahman et al., 2010). However, with the exception of the Coastal Zone Policy (Mowr, 2004), and the recently renewed National Agriculture Policy (MOA, 2011), climate change issues have not been sufficiently highlighted in the national policy regime. Given the importance of climate change and its potential adverse implications on economic development and people's lives and livelihoods, revision of sectoral policies and explicit inclusion of climate change impacts and considerations in these policies were highlighted by survey respondents as priorities.

Table 2. Year wise policy initiatives.

\begin{tabular}{|c|c|c|c|c|c|c|}
\hline 2005 & 2008 & 2009 & 2010 & 2011 & 2016 & 2018 \\
\hline \multirow{3}{*}{$\begin{array}{l}\text { Initial } \\
\text { NAPA } \\
(2005)\end{array}$} & \multirow{3}{*}{$\begin{array}{c}\text { BCCSAP } \\
(2008)\end{array}$} & \multirow{3}{*}{$\begin{array}{l}\text { Updated } \\
\text { NAPA } \\
(2009)\end{array}$} & \multirow{3}{*}{$\begin{array}{l}\text { Climate Change } \\
\text { Trust Act } 2010\end{array}$} & $\begin{array}{c}6^{\text {th }} \text { FYP } \\
(2011-2015)\end{array}$ & & \multirow{3}{*}{$\begin{array}{c}\text { Delta } \\
\text { Plan } 2100\end{array}$} \\
\hline & & & & $\begin{array}{l}\text { Perspective Plan } \\
\quad(2010-2021)\end{array}$ & $\begin{array}{c}7^{\text {th }} \text { FYP } \\
(2016-2020)\end{array}$ & \\
\hline & & & & $\begin{array}{c}\text { National Sustainable } \\
\text { Strategy } \\
(2010-2021)\end{array}$ & & \\
\hline
\end{tabular}




\subsection{Institutional Response}

\subsubsection{Role of the Formal Institutions}

\section{1) Ministry of Environment, Forest and Climate Change}

The Ministry of Environment, Forest and Climate Change (MoEFCC) is the lead institution for work on climate change issues. Previously, the ministry name was Ministry of Environment and Forest. On May 14 ${ }^{\text {th }}, 2018$, the cabinet changed the name to Ministry of Environment, Forest and Climate Change. The MoEFCC is the nodal agency in the administrative structure of the central government, for the planning, promotion, co-ordination and overseeing the implementation of environmental and forestry programmes. MoEF oversees all environmental matters in the country and is a permanent member of the Executive Committee of the National Economic Council. The Ministry led the Initial National Communication (INCom) to the UNFCCC, the BCCSAP, and commissioned the preparation of the Second National Communication (SNC) to the UNFCCC (MoEF, 2002; MoEF-UNDP, 2005). MoEFCC directs all climate change related policy issues and represents the country at international negotiations under the UNFCCC, a number of UNFCCC committees, and at conferences on multinational environmental agreements. The chief international negotiator on climate change for Bangladesh is from the MoEFCC. Nationally, the MoEFCC is the appointed institution to lead the implementation of climate change programming under the BCCSAP. The MoEFCC also chairs the Local Consultative Group (LCG) on Climate Change and Environment, which is an apex coordination mechanism between the government and development partners on environment and climate change programs.

With the advent of international financing modalities on climate change and the availability of seed financing for three consecutive years from the government, MoEFCC has become active in mobilizing funds and instituting mechanisms for managing climate change funds. In 2010-2011, MoEFCC formed a Climate Change Unit (CCU) to provide support to the Bangladesh Climate Change Trust Fund (BCCTF) (Mamun et al., 2018).

\section{2) Planning Commission}

The Planning Commission is another important institution established under the Ministry of Planning. It is responsible for preparing national plans (annual, five-year, and perspective) for the economic and social development of the country. It also prepares the "Annual Development Programme (ADP)" within the framework of the national plan to formulate policies for implementing plans. The Planning Commission determines objectives, goals and strategies of medium and short-term plans within the framework of long-term perspective and formulates policy measures for the achievement of planned goals and targets.

The Planning Commission has integrated climate resilience issues into national and local development planning by using improved instruments, methods and knowledge products. Over the years, through donor-assisted projects such as the Poverty, Environment and Climate Change Mainstreaming (PECM) Project, which is funded by UNDP and UNEP, adaptation has increasingly be- 
come significant in terms of national planning. All macro and perspective plans, including the "Perspective Plan" and the "National Sustainable Development Plan", acknowledge BCCSAP and include its climate change strategy (Figure 2).

Besides these two important institutions, there are some other government agencies with climate change functions. These are: Ministry of Finance, Ministry of Health, Bangladesh Meteorological Department (BMD), Ministry of Disaster Management and Relief, Ministry of Water Resources and its affiliated organization-Bangladesh water Development Board, Ministry of Agriculture and its affiliated organizations-Bangladesh Rice Research Institute (BIRI), Bangladesh Agricultural Research Council (BARC), Bangladesh Agricultural Research Institute (BARI), Ministry of Local Government, Rural Development \& Cooperatives, Bangladesh Institute of Development Studies (BIDS), etc.

\section{3) The Role of Local Government}

Local government institutions (LGIs), such as Union Parishads (UPs) and municipalities, are entities not limited to the provision of local needs, but is an instrument for the engagement of the community in local affairs. LGIs have a direct understanding of the needs of people in their communities. LGIs have been partnering with NGOs and donors to implement climate change initiatives. In addition, there are several standing committees within the local government that are related to climate change, e.g. disaster management, health, education, agriculture, etc.

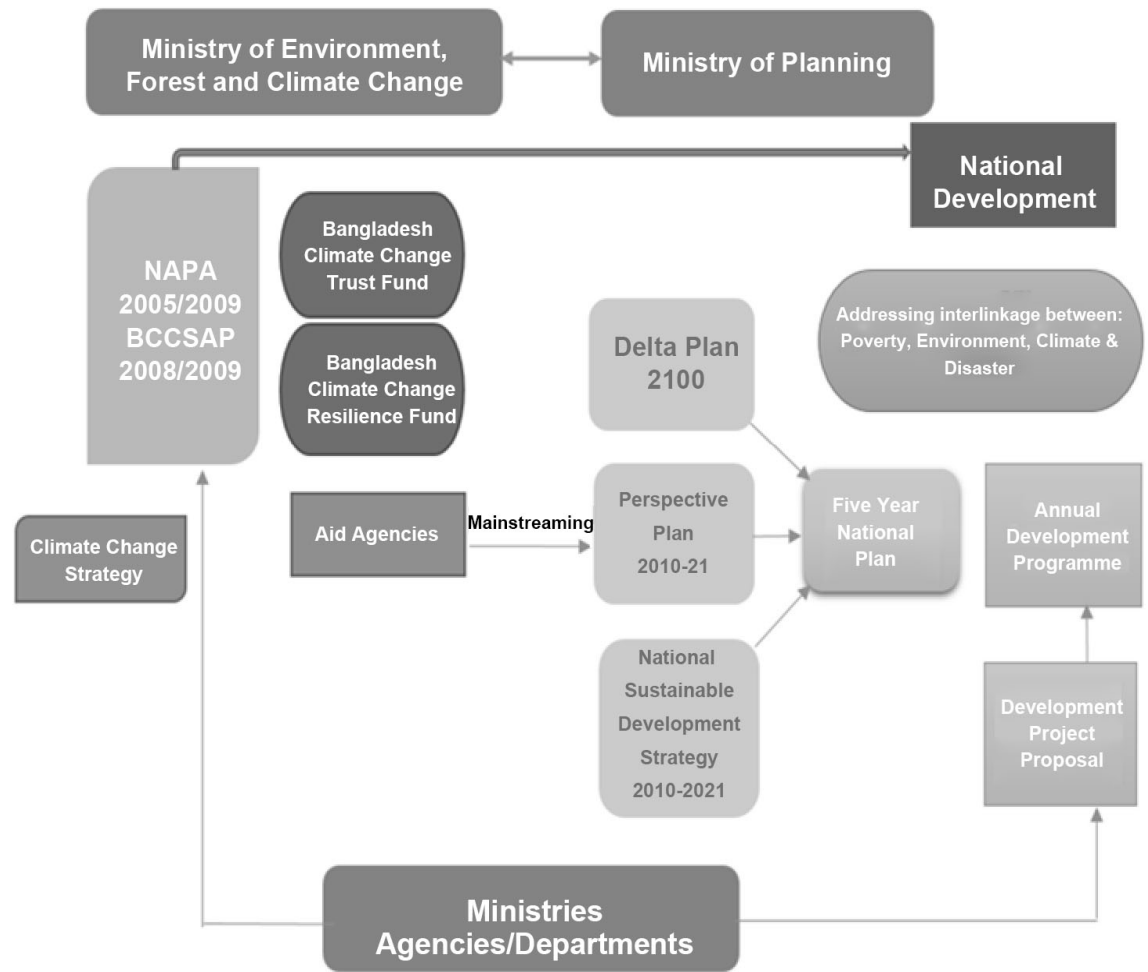

Figure 2. Institutional armaments (Adopted from Ayers et al., 2014). 


\subsubsection{Role of Non-Sate Actors}

The concept of Non State Actors (NSAs) has gained currency worldwide in the last couple of decades, as researchers, sociologists, activists and mediators have sought to comprehend and recognise the nature of interventions that fall without the purview of the State and yet have to be reckoned with if a certain beneficial action has to be enhanced or if a tough situation calls for sustainable denouement (Ulimwengu, 2007). Currently, several non-state actors are playing important roles in implementing and scaling up climate change adaptation and mitigation projects. This includes development partners, non-government organizations, and the private sector.

Currently, the donors, International NGOs (INGOs), and local NGOs are all playing a role in climate change adaptation and disaster preparedness. Many large national and well-known INGOs are in Bangladesh-The Red Crescent, CARE international, Oxfam, Save the Children, BRAC, and so forth. Additionally, while there are over 2000 local NGOs registered with the government that perform some program work in disaster preparedness and climate change adaptation, the best estimate is that only around 300 of them are currently active. Large projects are funded through consortiums or directly in collaboration with the national government, including a comprehensive disaster management program, the Chars Livelihood Programme, Shiree Economic Empowerment of the Poorest, National Alliance for Risk Reduction and Response Initiatives and Developing and Strengthening Humanitarian Assistance and Risk Reduction Initiatives.

Non-Government Organisations (NGOs) act as windows on applied knowledge and provide links to sources of information (Ahmad \& Rahman, 2011). State laws of Bangladesh allow NGOs to implement several projects voluntarily, but largely prohibit their participation in political decision-making processes. Even the state invites NGOs as a condition to receive aid, but displays arbitrary and co-opting attitudes towards NGOs that rarely ensure joint decisions in creating policy. The Bangladesh government formulated the BCCSAP in 2008 through a participatory process involving several NGOs and others (Lopa \& Ahmad, 2016). The NGOs in Bangladesh have incorporated climate change in most of their programs and developed extensive training of local government and communities across different ecosystems in the country. Bangladesh Centre for Advanced Studies (BCAS) and International Institute for Environment and Development (IIED) have organized ten worldwide International Conference on Community Based Adaptation (CBA) focusing on many initiative and efforts by countries to develop climate change adaptation in strategies and actions (Rahman, 2017). The Center for Natural Resources Studies (CNRS) developed a concept of "community-based wetland habitat restoration and fisheries management" which was funded by the Ford Foundation in two phases for seven years starting from July 1994, and demonstrated the concept in four locations. Later United Nations Development Programme (UNDP) and United States Agency for International Development (USAID) adopted the idea that CNRS demonstrated 
on small scale, and through the Department of Fisheries (DOF) and the Department of Environment (DOE) up-scaled the concept to other floodplains of Bangladesh. ACNRS demonstration project on community-based wetland habitat restoration and fisheries management was later up-scaled in Bangladesh in a number of projects funded by different agencies and implemented in different floodplains. Since this time, CNRS has been actively involved in various donor-supported government projects on fisheries and wetland management (Rahman \& Pokrant, 2014).

Local NGOs and community-based organizations (CBOs) have been trying to address the immediate impacts of climate change primarily through disaster risk reduction and adaptation initiatives. This includes organizing volunteer groups to respond to disasters, providing information on ways to reduce risk and vulnerability, constructing cyclone shelters, supporting alternative livelihoods, and adapting to extreme weather.

Recently, the private sector began to express interest in climate change adaptation and disaster preparedness. The Dhaka Chamber of Commerce and Industries (DCCI) organized training for its members on how to participate in the green economy and make their businesses more resilient to climate change. Shrimp farmers, for example, have demonstrated increasing understanding of the link between their business and climate change, e.g. increasing pest attacks on shrimps. In addition, a few private sector agencies have made investments in low-carbon development and have promoted energy efficient lighting, solar technologies, fuel efficient cooking stoves, among other initiatives (The Asia Foundation, 2012). In the areas of mitigation, Bangladesh has become the world leader in Solar House Systems with 4.5 million households using solar photovoltaic systems. Bangladesh Centre for Advanced Studies (BCAS), Grameen Shakti, Bangladesh Rural Advancement Committee (BRAC), Rahimafrooz, Bangladesh Council of Scientific and Industrial Research (BCSIR), Infrastructure Development Company Limited (IDCOL), etc. have contributed towards the dramatic increase in this sector. Improved stove, biogas plants and solar irrigation are also growing in number (Rahman, 2017).

\section{Assessing Climate Governance Challenges}

It appears clearly that there have been several initiatives taken by the government and other non-state actors. But Bangladesh still lacks a suitable institutional, decision making and planning structure for dealing with climate change. The reason behind this is mainly because of a highly centralised administration, fragmented and ineffective resource allocation and management systems, and project-oriented planning instead of resource-based planning (Koudstaal et al. 1999; MoEF, 2007). Likewise, the adaptation activities are confined to a pilot scale by government agencies, NGOs, and private research organizations, and they have shown limited capacity to integrate this learning into national and local development planning (Rahman et al., 2007; Mitchell, Tanner, \& Wilkinson 2006). 
The NGOs are active development partners in Bangladesh. They are involved in poverty alleviation, agricultural development, social safety nets, disaster risk reduction and health services in Bangladesh. NGOs are working in hard-to-reach areas with the poor, women, and marginal communities with pro-poor approaches. But it is found in many studies that many of the NGOs do not have adequate access to Bangladesh Climate Change Trust Fund (BCCTF) and BCCRF (Bangladesh Climate Resilient Fund) which is being supported by donors and development partners in Bangladesh (Rahman, 2015).

BCCTF dedicated to funding the implementation of climate change projects in Bangladesh from national sources. But this fund is facing a number of challenges, including a trend in reducing the amount allocated to the fund, a lack of quality proposals submitted, concerns over political influence in decision-making, limited control over all implementing ministries, and capacity constraints (Ministry of Finance, GOB, 2010).

Rules, regulations and policies related to climate adaptation are weak and consequently create problems for their implementation. Sharply defined guidelines for intersectoral jointaction are not available. Consequently, appropriate action plans are yet to be formulated. In some cases, political influence also forces the government institutions to work against the laws related to the protection of nature and the environment (Rahman, 2015).

Transparency International Bangladesh (TIB) (2017), a Berlin-based anti-corruption watchdog, in its report titled "Climate Financing and Good Governance in Project Implementation: Bangladesh Water Development Board Perspective" indicated that there have been irregularities in selecting project sites, contractors, project monitoring, peoples' participation in implementation process and openness of information. Gross irregularities and lack of transparency were found in six climate change impacts mitigation projects implemented by Bangladesh Water Development Board (BWDB). No project monitoring was done by the inspection teams of water resources ministry or Implementation Monitoring and Evaluation Division (IMED) of planning ministry. Besides, local people were not involved with the project implementation although there are specific law and policy for doing so while implementing water resources projects.

Local government provides important support, for example relief distribution, livelihood assistance, and reconstruction of major community services. But patronage relationships and bribery play a substantial role in how those responsibilities are discharged (Islam, Walkerden, \& Amati, 2017). After cyclone Aila, based on the damage each affected household was provided BDT 3000 - 5000 (US $\$ 43-72$ ) by the government to meet immediate basic needs. A study reveals that a higher proportion of wealthy households (19.4\%) received more than the stipulated single card and more ultra-poor households (8\%) were forced to pay bribes compared to other wealth categories. Following the immediate payment of cash transfers to households, the government provided 20 Kilograms of rice per month for each household affected by Aila. The same study shows that $99 \%$ 
of households received less rice than they were entitled to (Mahmud \& Prowse, 2012).

\section{Conclusion}

It's a really good move that the government has renamed the Ministry of Environment and Forest as the Ministry of Environment, Forest and Climate Change. But climate governance in Bangladesh still has a long way to go in order to build a climate resilient nation. Policies, strategies and action plans are in place to address climate change. But the main challenge remains in the implementation. Institutionalization of these policies, financial and technical capacity development of the implementing institutions; integration of science, policy and local knowledge; increasing inclusion of the local people within the development projects; a collaboration with the government, NGO, and local people are required for proper implementation of the policies for building resilience of the communities (Rahman, 2017). The government, and other stakeholders should ensure that the existing policies are effectively implemented prior to creating new policies, frameworks or mechanisms. There is a need for a supportive system of participatory management approach where the central and local government agencies, NGOs, the civil society, the private sectors and last, but not the least, citizens would work together as is necessary.

\section{Conflicts of Interest}

The authors declare no conflicts of interest regarding the publication of this paper.

\section{References}

Agarwal, A., Perrin, N., Chhatre, A., Benson, C. S., \& Kononen, M. (2012). Climate Policy Processes, Local Institutions, and Adaptation Actions: Mechanisms of Translation and Influence. Wiley Interdisciplinary Reviews: Climate Change, 3, 565-579. https://doi.org/10.1002/wcc.193

Ahmad, M., \& Rahman, A. (2011). Climate of Coastal Cooperation: The Stimulating Role of NGOs in Bangladesh (pp. 62-63). Leiden: Coastal \& Marine Union.

Ahmed, A. U. (2004). A Review of the Current Policy Regime in Bangladesh in Relation to Climate Change Adaptation, Reducing Vulnerability to Climate Change Project (RVCC). Khulna: CARE Bangladesh, $58 \mathrm{p}$.

Arts, B., \& Leroy, P. (2006). Institutional Dynamics in Environmental Governance. Dordrecht: Springer. https://doi.org/10.1007/1-4020-5079-8

Ayers, J. M., Huq, S., Faisal, A. M., \& Hussain, S. T. (2014). Mainstreaming Climate Change Adaptation into Development: A Case Study of Bangladesh. Wiley Interdisciplinary Reviews: Climate Change, 5, 37-51. https://doi.org/10.1002/wcc.226

Blatter, J. (2003). Beyond Hierarchies and Networks: Institutional Logics and Change in Transboundary Spaces. Governance, 16, 503-526. https://doi.org/10.1111/1468-0491.00226

Braun, D., \& Giraud, O. (2009). Politikinstrumenteim Kontext von Staat, Markt und Governance. In K. Schubert, \& N. C. Bandelow (Eds.), Lehrbuch der Politikfeldanalyse 2.0 
(pp. 159-187). Munich: Oldenbourg.

Das, S. (2009). Did the Hungry Tide Swallow the Tigers? The Times of India, 27, 1.

Davidson, S. (2008). A Review of the IFRC-Led Shelter Coordination Group Bangladesh Cyclone Sidr Response 2007-2008. Geneva: IFRC.

Doolin, M., Yang, M., Ye, P., \& Wang, Z. (2015). An Investigation of Climate Change Governance Trends in the United States: Challenges and Effective Drivers.

Eckstein, D., Künzel, V., \& Schäfer, L. (2017). Global Climate Risk Index 2018. Bonn: Germanwatch.

Edwards, I., Burton, D., \& Baker-Jones, M. (2017). Risk Management: Governance and Climate Change Risk. Governance Directions, 69, 82.

Frederickson, H. G., \& Smith, K. B. (2003). The Public Administration Theory Primer. Boulder: Westview Press.

Fröhlich, J., \& Knieling, J. (2013). Conceptualising Climate Change Governance. In Climate Change Governance (pp. 9-26). Berlin Heidelberg: Springer. https://doi.org/10.1007/978-3-642-29831-8_2

Gaillard, J. C. (2010). Vulnerability, Capacity and Resilience: Perspectives for Climate and Development Policy. Journal of International Development, 22, 218-232.

https://doi.org/10.1002/jid.1675

Glasbergen, P. (1998). Co-Operative Environmental Governance: Public-Private Agreements as a Policy Strategy. Dordrecht, Boston: Kluwer Academic Publishers. https://doi.org/10.1007/978-94-011-5143-6

Hanf, K., \& Scharpf, F. W. (1978). Interorganizational Policy Making: Limits to Coordination and Central Control. London, Beverly Hills: Sage Publications.

Hill, C. J., \& Lynn, L. E. (2005). Is Hierarchical Governance In Decline? Evidence from Empirical Research. Journal of Public Administration Research and Theory, 15, 173-196. https://doi.org/10.1093/jopart/mui011

IPS, Inter Press Service (2014). Climate Governance in Africa: A Handbook for Journalists, Africa.

Islam, R., Walkerden, G., \& Amati, M. (2017). Households' Experience of Local Government during Recovery from Cyclones in Coastal Bangladesh: Resilience, Equity, and Corruption. Natural Hazards, 85, 361-378. https://doi.org/10.1007/s11069-016-2568-6

Jordan, A., Huitema, D., Van Asselt, H., \& Forster, J. (Eds.) (2018). Governing Climate Change: Polycentricity in Action? Cambridge: Cambridge University Press. https://doi.org/10.1017/9781108284646

Kabir, R., Khan, H. T., Ball, E., \& Caldwell, K. (2016). Climate Change Impact: The Experience of the Coastal Areas of Bangladesh Affected by Cyclones Sidr and Aila. Journal of Environmental and Public Health, 2016, Article ID: 9654753. https://doi.org/10.1155/2016/9654753

Kettl, D. F. (2002). Environmental Governance: A Report on the Next Generation of Environmental Policy. Washington DC: Brookings Institution Press.

Koudstaal, R., Werners, S. E., Rahman, A., Huq, S., \& Ahmed, U. A. (1999). Considering Adaptation to Climate Change towards a Sustainable Development in Bangladesh, South Asia Region. Washington DC: The World Bank.

Lopa, F. G. R., \& Ahmad, M. M. (2016). Participation of CSOs/NGOs in Bangladeshi Climate Change Policy Formulation: Co-Operation or Co-Optation? Development in Practice, 26, 781-793. https://doi.org/10.1080/09614524.2016.1200536

Mahmud, T., \& Prowse, M. (2012). Corruption in Cyclone Preparedness and Relief Ef- 
forts in Coastal Bangladesh: Lessons for Climate Adaptation? Global Environmental Change, 22, 933-943. https://doi.org/10.1016/j.gloenvcha.2012.07.003

Mamun, M. A., Farhana, R., \& Rahman, M. M. (2018). The Role of Bangladesh Climate Change Trust for the Implementation of Climate Change Projects in Bangladesh: An Empirical Study. European Journal of Business and Social Sciences, 7, 1-16.

Marin, B., \& Mayntz, R. (1991). Policy Networks: Empirical Evidence and Theoretical Considerations. Frankfurt am Main: Boulder.

Mayntz, R. (2006). Governance Theory als fortentwicklelte Steuerungstheorie? In: G. F. Schuppert (Ed.), Governance-Forschung. Vergewisserung über Stand und Entwicklungslinien (pp. 11-20). Baden-Baden: Nomos-Verl.-Ges.

Meadowcroft, J. (2009). Climate Change Governance. Washington DC: The World Bank. https://doi.org/10.1596/1813-9450-4941

Ministry of Environment and Forests (MoEF) (2005). National Adaptation Programme of Action, 2009 (Updated Version). Dhaka: Government of the People's Republic of Bangladesh.

Ministry of Finance (2014). Bangladesh: Climate Fiscal Framework. Dhaka: Government of the People's Republic of Bangladesh.

Ministry of Finance, Government of Bangladesh (2010). Evaluation of the Implementation of the Paris Declaration, Phase II, Country Evaluation Bangladesh. Final Report, Dhaka: Ministry of Finance of Bangladesh.

Mitchell, T., Tanner, T., \& Wilkinson, E. (2006). Overcoming the Barriers: Mainstreaming Climate Change Adaptation in Developing Countries. Tearfimd Climate Change Briefing Paper 1, Brighton: Institute of Development Studies.

MOA (2011). National Agriculture Policy (Final Draft): Shared for Parliamentary Review. Dhaka: Ministry of Agriculture (MOA).

MoEF (2002). Initial National Communication. Dhaka: Ministry of Environment and Forest (MOEF).

MoEF (2007). Bangladesh Capacity Development Action for Sustainable Environmental Governance. Bangladesh, Dhaka: Ministry of Environment and Forests, Government of the People's Republic of Bangladesh.

MOEF-UNDP (2005). National Adaptation Programme of Action. Bangladesh, Dhaka: Ministry of Environment and Forest (MOEF), Government of the People's Republic of Bangladesh and United Nations Development Programme (UNDP).

MOWR (2004). Coastal Zone Policy. Dhaka: Ministry of Water Resources (MOWR).

Osborne, D., \& Gaebler, T. (1992). Reinventing Government: How the Entrepreneurial Spirit Is Transforming the Public Sector. Reading, MA: Addison-Wesley.

Ostrom, E. (1990). Governing the Commons: The Evolution of Institutions for Collective Action. Cambridge: Cambridge University Press.

https://doi.org/10.1017/CBO9780511807763

Oxfam International (2011). Owning Adaptation Factsheet: Bangladesh. Oxford: Oxfam International.

Paul, B. K. (2009). Why Relatively Fewer People Died? The Case of Bangladesh's Cyclone Sidr. Natural Hazards, 50, 289-304. https://doi.org/10.1007/s11069-008-9340-5

Pierre, J. (2002). Introduction: Understanding Governance. In: J. Pierre (Ed.), Debating Governance. Oxford: Oxford University Press.

Pierre, J., \& Peters, R. G. (2000). Governance, Politics and the State. London: Macmillan.

Rahman, A. (2015). Environmental Governance and Growth. The Daily Star, March 12 
2015.

Rahman, A. (2017). Climate Change Challenges and Its Preparation in Bangladesh. Dhaka: Business Times.

Rahman, A. A., Alam, M., Alam, S. S., Uzzaman, R., Rashid, M., \& Rabbani, G. (2007). Human Development Report 2007, Background Paper on Risks, Vulnerability and Adaptation in Bangladesh. Dhaka: Bangladesh Centre for Advanced Studies.

Rahman, A., Rabbani, G., Muzammil, M., Alam, M., Thapa, S., Rakshit, R., \& Inagaki., H. (2010). Scoping Assessment of Climate Change Adaptation in Bangladesh, Summary Report (p. 24). Bangkok: Adaptation Knowledge Platform.

Rahman, M., \& Pokrant, B. (2014). Reflections on Working with Communities and Community-Based Projects in Bangladesh. In $M^{2}$ Models and Methodologies for Community Engagement (pp. 215-235). Singapore: Springer. https://doi.org/10.1007/978-981-4585-11-8_13

Rhodes, R. A. W. (1997). Understanding Governance: Policy Networks, Governance, Reflexivity and Accountability. Buckingham: Open University Press.

Rosenau, J. N. (1992). Post-Modernism and the Social Sciences: Insights, Inroads and Intrusions. Princeton, NJ: Princeton University Press. https://doi.org/10.1515/9781400820610

Roy, K., Kumar, U., Mehedi, H., Sultana, T., \& Ershad, D. M. (2009). Initial Damage Assessment Report of Cyclone AILA with Focus on Khulna District (p. 31). Khulna: Unnayan Onneshan-Humanity Watch-Nijera Kori.

Salamon, L. M., \& Elliott, O. V. (2002). The Tools of Government: A Guide to the New Governance. Oxford, New York: Oxford University Press.

Soltwedel, R. (2005). MarktwirtschaftlicheInstrumente. In: ARL Akademiefür Raumforschung und Landesplanung (Ed.), Handwörterbuch der Raumordnung (pp. 625-631). Hannover: Akad. fürRaumforschung und Landesplanung.

Stoker, G. (1998). Governance as Theory: Five Propositions. International Social Science Journal, 50, 17-28. https://doi.org/10.1111/1468-2451.00106

The Asia Foundation (2012). A Situation Analysis of Climate Change Adaptation Initiatives in Bangladesh. Dhaka: Bangladesh.

Transparency International Bangladesh (TIB) (2017). Climate Finance and Governance in Project Implementation: The Case of Bangladesh Water Development Board.

Ulimwengu, J. (2007). The Role of Non-State Actors. In 7th African Governance Forum.

UO-Oxfam (2008). Climate Change: As If Development Mattered (p. 30). Dhaka: Unnayan Onneshan (UO) and Oxfam GB Bangladesh (Mimeo).

Van Nieuwaal, K., Driessen, P. P. J., Spit, T., \& Termeer, C. (2009). Governance of Adaptation: A State of the Art of Governance, Literature on Adaptation to Climate Change: Towards a Research Agenda. IOP Conference Series: Earth and Environmental Science, 6, Article ID: 362019.

https://doi.org/10.1088/1755-1307/6/6/362019

Vidal, J. (2017). From Heatwaves to Hurricanes, Floods to Famine: Seven Climate Change Hotspots. The Guardian, June 23. 